\title{
An Overview on Novel Coronavirus (COVID-19)
}

\section{Suresh Ghotekar ${ }^{1 *}$, Shreyas Pansambal ${ }^{2}$ and Rajeshwari Oza}

${ }^{1}$ Department of Chemistry, Sanjivani Arts, Commerce and Science College, Savitribai Phule Pune University, Maharashtra, India

${ }^{2}$ Department of Chemistry, S.N. Arts, D.J.M. Commerce and B.N.S. Science College, Savitribai Phule Pune University, Maharashtra, India

*Corresponding Author: Suresh Ghotekar, Department of Chemistry, Sanjivani Arts, Commerce and Science College, Savitribai Phule Pune University, Maharashtra, India.
Received: March 242020

Published: May 20, 2020

(C) All rights are reserved by Suresh

Ghotekar., et al.
In December 2019, a novel coronavirus (COVID-19) was reported in Wuhan, a city of 11 million people in central China. The initial cases were connected to exposures in a seafood market in Wuhan [1]. As of March 23 (11.00 AM), 2020, the WHO reported 294110 confirmed cases and 12944 confirmed deaths in 187 countries of the whole world. The infected people were experienced respiratory illness and coughs. Therefore, pathogen was soon identified as a COVID-19 which is closely related to sever acute respiratory syndrome CoV (SARS-CoV). Currently, there is no completely specific treatment against the COVID-19. Therefore, identifying effective antiviral medicines to combat the disease is an imperatively needed. An efficient approach to effective drug discovery is to test whether the existing antiviral drugs are effective in treating related COVID-19 viral infections. Also, clinical researches are rapidly growing on to find out the solution of COVID-19.

Till date, there are several drugs tested against COVID-19, such as favipiravir (T-705), remdesivir (GS- 5734), interferon, ribavirin, lopinavir-ritonavir, corticosteroids, nafamostat, penciclovir, chloroquine phosphate, nitazoxanide and chloroquine [2-4]. Nevertheless, unfortunately the aforementioned medicines are not able to perfectly cure COVID-19.

So, our suggestion is that protect yourself and others from infected person of COVID-19 by washing your hands or using a sanitizers/alcohol based rub frequently and not touching your face. Therewithal, follow the guidelines of WHO, central and state governments. This is one of best and unique platform to fight against COVID-19 and save many lives.

\section{Bibliography}

1. Wu Zunyou and Jennifer M McGoogan. "Characteristics of and important lessons from the coronavirus disease 2019 (COVID-19) outbreak in China: summary of a report of 72314 cases from the Chinese Center for Disease Control and Prevention". Journal of the American Medical Association (2020).
2. Wang Manli., et al. "Remdesivir and chloroquine effectively inhibit the recently emerged novel coronavirus (2019-nCoV) in vitro". Cell Research 30.3 (2020): 269-271.

3. Lim Jaegyun., et al. "Case of the index patient who caused tertiary transmission of COVID-19 infection in Korea: the application of lopinavir/ritonavir for the treatment of COVID-19 infected pneumonia monitored by quantitative RT-PCR". Journal of Korean Medical Science 35.6 (2020): e79.

4. Gao Jianjun., et al. "Breakthrough: Chloroquine phosphate has shown apparent efficacy in treatment of COVID-19 associated pneumonia in clinical studies". Bioscience Trends 14.1 (2020): 72-73.

\section{Assets from publication with us}

- Prompt Acknowledgement after receiving the article

- Thorough Double blinded peer review

- Rapid Publication

- Issue of Publication Certificate

- High visibility of your Published work Website: www.actascientific.com/ Submit Article: www.actascientific.com/submission.php Email us: editor@actascientific.com Contact us: +919182824667 